\title{
Gas Chromatographic and Mass Spectroscopic (GC-MS) Analysis of Rhizome of Acorus Calamus Linn. for Identification of Potent Antimicrobial Bio-active Compounds
}

\author{
S. Prabha*, J. Kumar \\ Department of Botany, Ranchi University, Ranchi - 834008, Jharkhand, India
}

Received 30 July 2020, accepted in final revised form 22 September 2020

\begin{abstract}
Acorus calamus Linn. has wide applications as a herbal medicine since its roots, leaves and rhizome exhibit antimicrobial and insecticidal activities. The objective of this study was to identify some compounds in Acorus calamus Linn., which may be responsible for its antimicrobial activity. Gas Chromatography-Mass Spectroscopy (GC-MS) analysis, for investigation of the compounds present, of the petroleum ether extract of Acorus calamus Linn. rhizome suggested presence of five compounds (which showed close match with those of the GC-MS database main library of Novocatalyz) viz., spiro [2,4,5,6,7,7a-hexahydro-2oxo-4,4,7a-trimethylbenzofuran]-7,2' -(oxirane); 9-octadecenoic acid (Z)-, phenylmethyl ester; shyobunone; asarone [syn. $\alpha$-asarone]; benzene, 1,2,3-trimethoxy-5-(2-propenyl)-. $\alpha$ asarone and benzene, 1,2,3-trimethoxy-5-(2-propenyl)- have been reported to be sensitive against plant pathogen and may be responsible for its anti-fungal activity. As per the compound contents of this plant, studies suggest that Acorus calamus Linn. could be a potential herbal medicine against certain microbial diseases.
\end{abstract}

Keywords: Acorus calamus Linn.; Bioactive compound; GC-MS analysis; $\alpha$-Asarone.

(C) 2021 JSR Publications. ISSN: 2070-0237 (Print); 2070-0245 (Online). All rights reserved. doi: http://dx.doi.org/10.3329/jsr.v13i1.48452

J. Sci. Res. 13 (1), 263-273 (2021)

\section{Introduction}

Acorus calamus has been used widely as a herbal medicine as its roots, leaves and rhizomes (Figs. 1 and 2) have been reported to exhibit anti-microbial and insecticidal activities and as such it can be used for prevention and treatment of a wide number of diseases such as rheumatoid arthritis, gastrointestinal disorders, and various other mental ailments including epilepsy [1-3]. A. calamus is a traditional medicine [4]. In Ayurvedic medicine, A. calamus is an important herb, and is valued as a 'rejuvenator' for the brain and nervous system, and as a remedy for digestive disorders. Acorus calamus is also used as a herbal medicine for treating inflammation of eyes [5].

Research works have evaluated antimicrobial activity of Acorus calamus rhizome and leaf extracts obtained with different solvents viz., petroleum ether, chloroform, hexane and

\footnotetext{
* Corresponding author: smrity80@gmail.com
} 
ethyl acetate. Petroleum ether extract of Acorus calamus has been found to be very effective against pathogenic fungi. Petroleum ether extract of Acorus calamus has been reported to exhibit $100 \%$ inhibition of Sclerotium rolfsii with minimum inhibitory concentration (MIC) of $10.4 \mathrm{mg} / \mathrm{mL}$ [6].

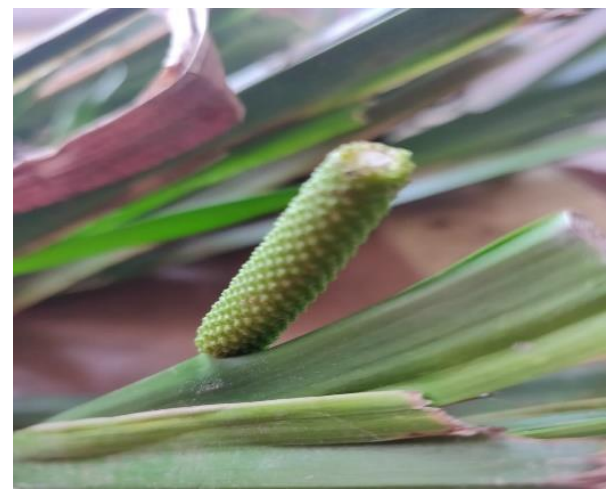

Fig. 1. Acorus calamus plant.

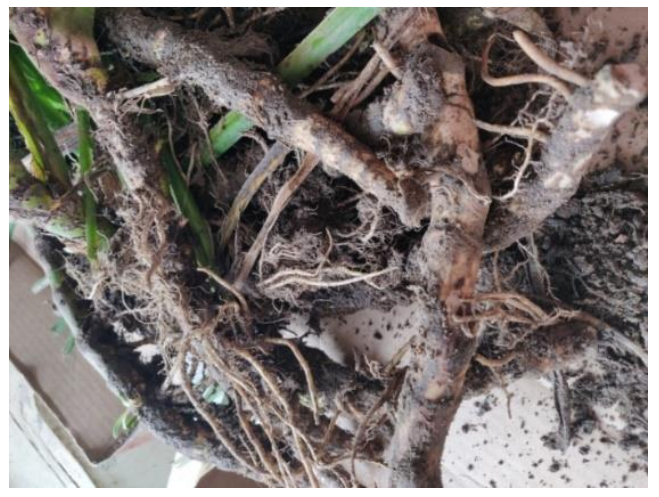

Fig. 2. Rhizome of Acorus calamus.

Researchers have also identified some of the active compounds, which impart therapeutic potential to A. calamus. Antioxidant activity of ethanolic extract of Acorus calamus has been reported to be linked to its phenolics and flavonoid contents. A positive correlation of its anti-oxidant capacity with its phenolic and flavonoid contents has been reported for Acorus calamus Linn. rhizome [7]. As per some of the preliminary phytochemical studies, A. calamus is found to contain some secondary metabolites such as flavonoids, glycosides, tannins, saponins, volatile oil polyphenolic compounds, mucilage, etc. [8]. Several volatile bioactive organic compounds such as $\beta$-asarone, linalool, methyl eugenol, etc. have also been reported in Nepalese Acorus calamus rhizomes [9]. $\alpha$ - and $\beta$ asarones, caryophyllene, isoasarone, methyl isoeugenol, and safrol have been identified as the major chemical constituents in A. calamus, of which $\alpha$ - and $\beta$-asarones have been identified as responsible for imparting anti-microbial potential to A. calamus [10-14].

Antimicrobial activity of $\beta$-asarone derived from A. calamus against bacteria, yeasts and filamentous fungi has been evaluated and it was found that $\beta$-asarone exhibited high activity against filamentous fungi: Trichophyton rubrum, Microsporum gypseum and Penicillium marneffei [15]. It has also been observed that the antifungal activity of $A$. calamus is because of haem peroxidase, which is synthesized and accumulated in the plant during pathogenesis [16].

Some studies, in vitro and in vivo, however, have raised concerns relating to sideeffects of $A$. calamus as it was observed to induce malignant tumours due to $\beta$-asarone. Nevertheless, there are several polypoid varieties of A. calamus, which do not contain toxic materials. It has been argued that for toxicity, products should contain no or a negligible amount of $\beta$-asarone [17]. Ethanol extract of A. calamus (upto a dose of 600 $\mathrm{mg} / \mathrm{kg} \mathrm{BW}$ ) has been reported to lack potential toxicity in studies relating to rats [18]. 
Given the presence of a number of compounds in Acorus calamus, this study seeks to identify few phytochemical compounds that may be responsible for its therapeutic properties using Gas Chromatography-Mass Spectroscopy (GC-MS) analysis.

\section{Materials and Methods}

\subsection{Collection, identification and authentication of plants material}

Plant materials were collected in wild condition from various localities of Ranchi. The collected A. calamus plant material was preserved in the form of herbarium, which matched with the specimen No. 2574 of M. R. Almeida, preserved in the Blatter Herbarium, St. Xavier's College, Mumbai, India. The characteristics of the plant were identified using 'Flora of Bihar and Orissa' [19]. The material was then washed with distilled water 2-3 times and shade dried. The dried plant material was then ground using grinder. The powder, thus obtained, were relocated to air tight jars and stored in the dark for future use.

\subsection{Sample preparation}

$10 \mathrm{~g}$ of powdered plant material was soaked overnight in $50 \mathrm{~mL}$ of petroleum ether (40-60 $\left.{ }^{\circ} \mathrm{C}\right)$ separately with intermittent shaking. The extract was then filtered through Whattman no. 1 filter paper and the filtrates were collected separately. To the residue $50 \mathrm{~mL}$ of solvent (in which the powder was soaked) was added, stirred well and left for $4 \mathrm{~h}$. at room temperature with intermittent shaking. The extracts were filtered again and the filtrates were collected. This procedure was repeated once again and the filtrates of the plant was pooled separately. The filtrate, thus obtained, was transferred separately to pre-weighed evaporating dishes and the solvent was evaporated. The sample so obtained was stored in an air tight poly-tube and sent to Novacatalyz Laboratory (based in Bangalore) for GCMS analysis for authentic identification of constituent compounds present in the plant extracts.

\subsection{Gas chromatography-mass spectroscopy (GC-MS) analysis}

\subsubsection{Preparation of extract}

$0.1080 \mathrm{~g}$ of sample was put into a $5 \mathrm{~mL}$ volumetric flask (VF) and then dissolved in $2 \mathrm{~mL}$ of solvent, which was then sonicated and made up to mark with solvent. $0.1 \mathrm{~mL}$ of solvent was pipetted out from the solution and it was mixed with $0.9 \mathrm{~mL}$ of methanol solvent in a separate flask to make the final volume $1 \mathrm{~mL}$.

\subsubsection{Method of analysis}

Modified method was used for GC-MS analysis [20], which is as follows. Helium gas was used as a carrier gas at a constant flow rate of $1 \mathrm{~mL} / \mathrm{min}$. An injection volume of $1 \mu \mathrm{L}$ was 
employed. The injector temperature was adjusted to $280{ }^{\circ} \mathrm{C}$. The ion source temperature was adjusted to $230{ }^{\circ} \mathrm{C}$. The oven temperature was programmed from $150{ }^{\circ} \mathrm{C}$ for $2 \mathrm{~min}$, to $290{ }^{\circ} \mathrm{C}$ at $8{ }^{\circ} \mathrm{C}$ per min. and held for $10 \mathrm{~min}$. Mass spectra were taken at $\mathrm{eV}$; a scan interval of 0.5 second and 40 to $800 \mathrm{Da}$. Total GC-MS running time was $30 \mathrm{~min}$.

\section{Results and Discussion}

\subsection{Compound analysis}

GC-MS analysis (for investigation of the compounds present) of the petroleum ether extract of A. calamus rhizome suggested presence of five compounds, viz., Spiro[2,4,5,6,7,7a-hexahydro-2-oxo-4,4,7a-trimethylbenzofuran]-7,2'-(oxirane); 9Octadecenoic acid (Z)-, phenylmethyl ester $\left(\mathrm{C}_{25} \mathrm{H}_{40} \mathrm{O}_{2}\right)$; Shyobunone; $\alpha$-Asarone; and Benzene, 1,2,3-trimethoxy-5-(2-propenyl)- $\left(\mathrm{C}_{12} \mathrm{H}_{16} \mathrm{O}_{3}\right)$ (Tables 1-3).

Table 1. Compounds and their synonyms.

\begin{tabular}{|c|c|c|}
\hline Sl. No. & Compound name & Synonyms \\
\hline 1 & $\begin{array}{l}\text { Spiro }[2,4,5,6,7,7 \text { a-hexahydro-2- } \\
\text { oxo-4,4,7a-trimethylbenzofuran]- } \\
7,2 \text {-(oxirane) }\end{array}$ & No synonym. \\
\hline 2 & $\begin{array}{l}\text { 9-0ctadecenoic acid (Z)-, } \\
\text { phenylmethyl ester }\end{array}$ & $\begin{array}{l}\text { 1. Benzyl oleate. } \\
\text { 2. Benzyl (9Z)-9-octadecenoate. }\end{array}$ \\
\hline 3 & Shyobunone & No synonym. \\
\hline 4 & Asarone & $\begin{array}{l}\text { 1. (E)- 2,4,5-Trimethoxypropenylbenzene. } \\
\text { 2. trans-2,4,5-Trimethox***ypropenylbenzene } \\
\text { 3. Benzene, 1,2,4-trimethoxy-5-(1-propenyl)-, (E)- } \\
\text { 4. Benzene, 1,2,4-trimethoxy-5-propenyl)-, (E)- } \\
\text { 5. Asarone. } \\
\text { 6. Asarone, trans- } \\
\text { 7. } \alpha \text {-Asarone. } \\
\text { 8. trans-Asarone. }\end{array}$ \\
\hline 5 & $\begin{array}{l}\text { Benzene, 1,2,3-trimethoxy-5-(2- } \\
\text { propenyl)- }\end{array}$ & $\begin{array}{l}\text { 1. Benzene, 5-allyl-1,2,3-yrimethoxy. } \\
\text { 2. Elemicin. } \\
\text { 3. 3,4,5-Trimethoxyallylbenzene. } \\
\text { 4. 5-Allyl-1,2,3-trimethoxybenzene. } \\
\text { 5. 1,2,3-Trimethoxy-5-(2-propenyl)-benzene. } \\
\text { 6. 1,2,3-Trimethoxy-5allylbenzene. } \\
\text { 7. 4-Allyl-1,2,6-trimethoxybenzene. } \\
\text { 8. Benzene, 5-(2-propenyl)-1,2,3-trimethoxy. }\end{array}$ \\
\hline
\end{tabular}

Table 2. Compounds and their sources.

\begin{tabular}{|c|c|c|c|c|c|}
\hline $\begin{array}{l}\text { Sl. } \\
\text { No. }\end{array}$ & Compound & $\begin{array}{l}\text { Chemical } \\
\text { Formula }\end{array}$ & Class & $\begin{array}{l}\text { Molecular } \\
\text { weight }\end{array}$ & Source \\
\hline 1. & $\begin{array}{l}\text { Spiro [2,4,5,6,7,7a- } \\
\text { hexahydro-2-oxo-4,4,7a- } \\
\text { trimethylbenzofuran]-7,2' } \\
\text {-(oxirane) }\end{array}$ & $\mathrm{C}_{12} \mathrm{H}_{16} \mathrm{O}_{3}$ & - & 208 & $\begin{array}{l}\text { 1. Isodon excise, } \\
\text { 2. Loranthus micranthus }\end{array}$ \\
\hline 2 & $\begin{array}{l}\text { 9-0ctadecenoic acid (Z)-, } \\
\text { phenylmethyl ester }\end{array}$ & $\mathrm{C}_{25} \mathrm{H}_{40} \mathrm{O}_{2}$ & Oleic acid & 372 & $\begin{array}{l}\text { 1. Cleidion nitidum } \\
\text { (Muell. - Arg.) Thw. }\end{array}$ \\
\hline
\end{tabular}




\begin{tabular}{|c|c|c|c|c|c|}
\hline 3. & Shyobunone & $\mathrm{C}_{15} \mathrm{H}_{24} \mathrm{O}$ & $\begin{array}{l}\text { Ketone } \\
\text { compound }\end{array}$ & 220 & $\begin{array}{l}\text { ex Kurz., } \\
\text { 2. Sarcostemma } \\
\text { secamone }(\mathrm{L}) \text { Bennet, } \\
\text { 3. Jatropha } \\
\text { tanjorensis } * \text { J.L.Ellis } \\
\text { \&Saroja } \\
\text { Acorus calamus }\end{array}$ \\
\hline 4. & Asarone [syn. A-+asarone] & $\mathrm{C}_{12} \mathrm{H}_{16} \mathrm{O}_{3}$ & $\begin{array}{l}\text { Aromatic } \\
\text { compound }\end{array}$ & 208 & $\begin{array}{l}\text { 1. Acorus calamus } \\
\text { 2. Acorus gramineus }\end{array}$ \\
\hline 5. & $\begin{array}{l}\text { Benzene, 1,2,3- } \\
\text { trimethoxy-5-(2- } \\
\text { propenyl)- }\end{array}$ & $\mathrm{C}_{12} \mathrm{H}_{16} \mathrm{O}_{3}$ & $\begin{array}{l}\text { Phenyl- } \\
\text { propenes }\end{array}$ & 208 & $\begin{array}{l}\text { 1. Gloriosa superb } \\
\text { 2. Dalbergia } \\
\text { barbidensis }\end{array}$ \\
\hline
\end{tabular}

Table 3. Phytochemical compounds (with their biological activity) found in Acorus calamus.

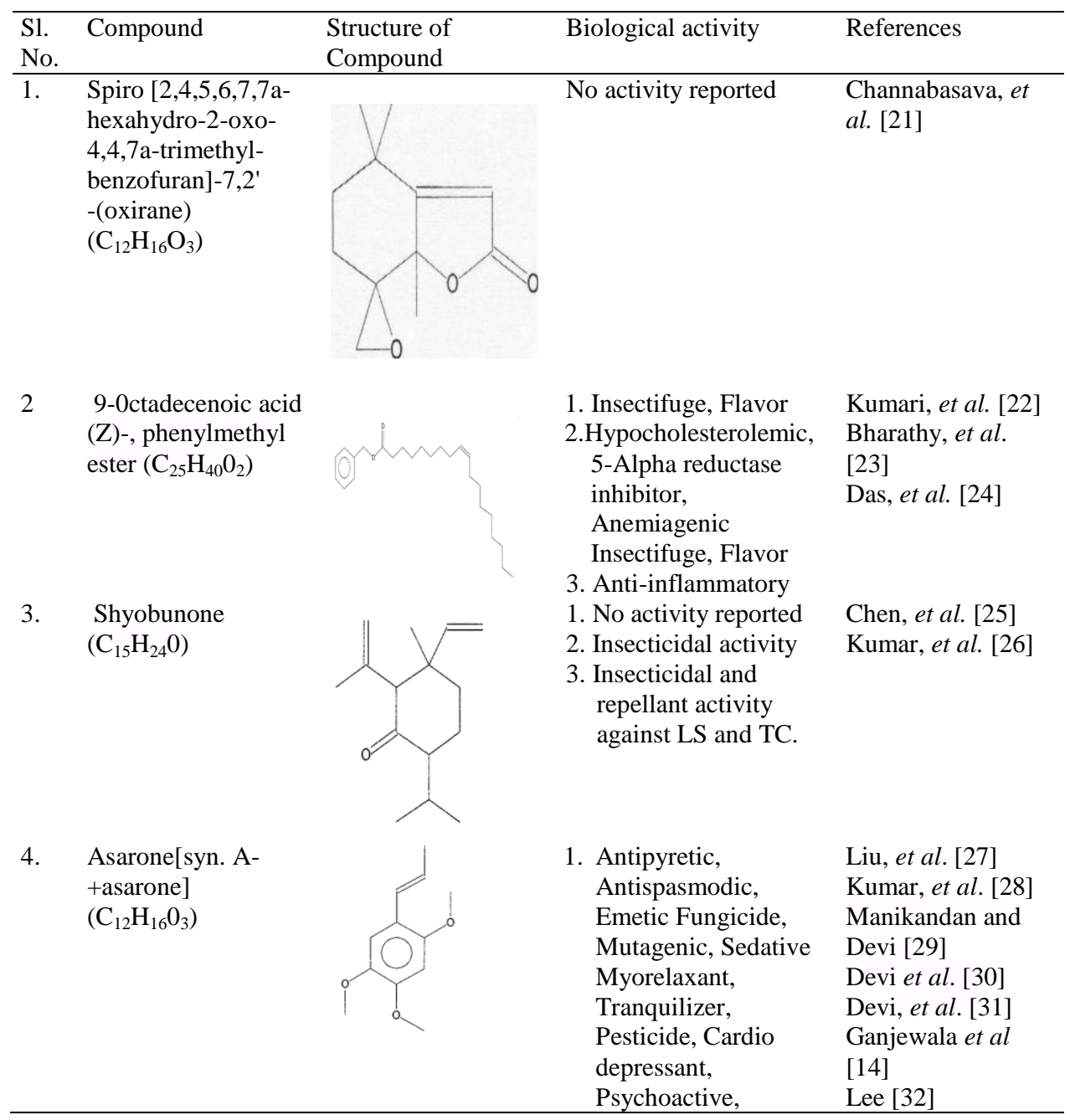




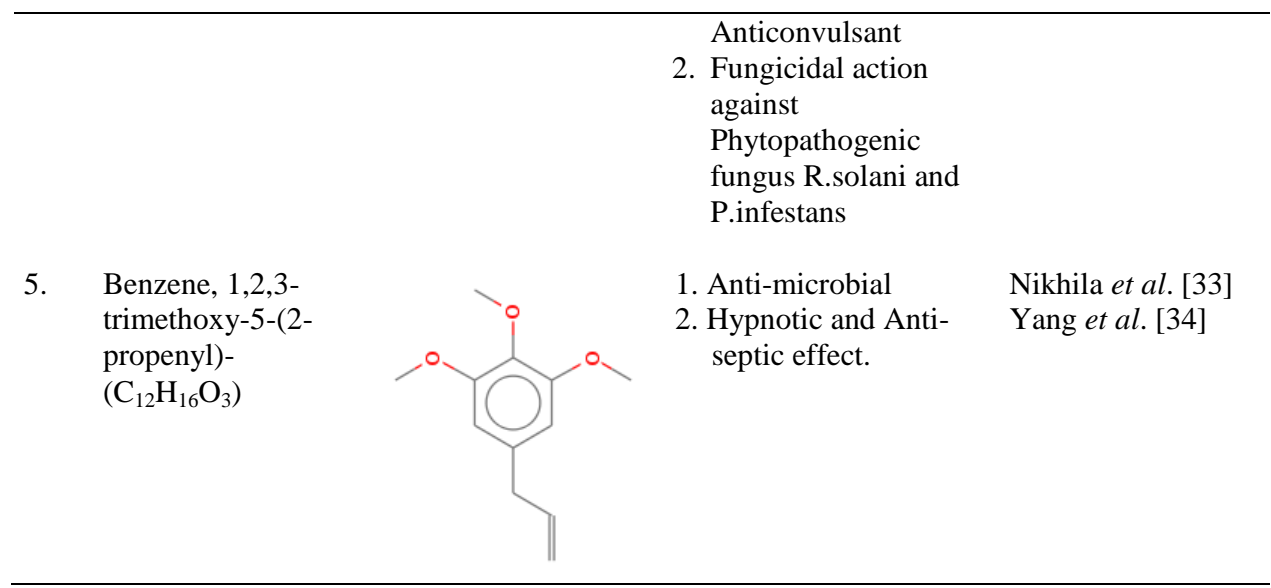

3.2. Spiro [2,4,5,6,7,7a-hexahydro-2-oxo-4,4,7a-trimethylbenzofuran]-7,2'-(oxirane) $\left(\mathrm{C}_{12} \mathrm{H}_{16} \mathrm{O}_{3}\right)$

GC-MS analysis suggested the presence of Spiro in Acorus calamus (Fig. 3). This compound is found to be present in various other plants, including Loranthus micranthus. Channabasava et al. [21] through GC-MS analysis of methanol extracts of Loranthus micranthus reported presence of spiro, but it was not found to exhibit any biological activity.

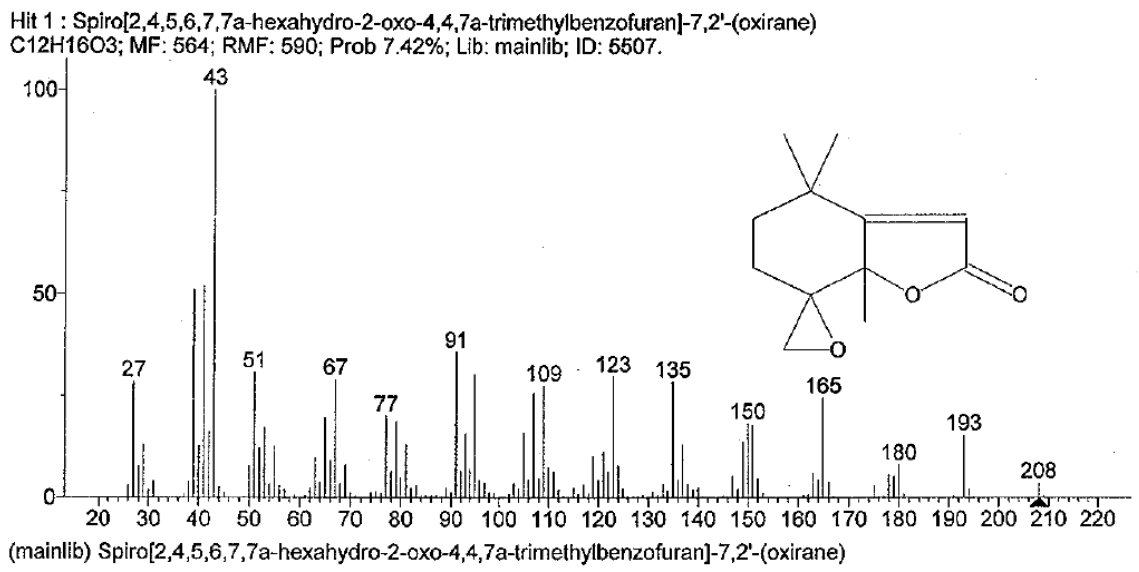

Fig. 3. Chromatogram of compound Spiro [2,4,5,6,7,7a-hexahydro-2-oxo-4,4,7atrimethylbenzofuran]-7,2'-(oxirane).

\subsection{9-Octadecenoic acid (Z)-, phenylmethyl ester}

GC-MS analysis suggested the presence of this compund in Acorus calamus (Fig. 4). This compound present in several plants, including Sarcostemma secamone, Jatropha tanjorensis, and $C$. Nitidum has been reported to exhibit anti-inflammatory activity and 
some biological activity. Kumari et al. [22] investigated possible bioactive components of whole plant of Sarcostemma secamone using GC-MS analysis and found 14 compounds in the ethanolic extract in which 9-octadecenoic acid (Z)-, phenyl methyl ester (comprising $6.96 \%$ of all the found compounds) was found to show some biological activity. Bharathy et al. [23] carried out GC-MS chromatogram of ethanolic extract of Jatropha tanjorensis leaves and identified 16 phyto-constituents and reported that 90ctadecenoic acid (Z)-, phenyl methyl ester (belonging to ester class) exhibited antiinflammatory activity. Das et al. [24] reported presence of 9-octadecenoic acid (Z)-, phenyl methyl ester (1.47\%) (belonging to oleic acid ester class) as a major compound in the ethanolic extracts of leaves of $C$. Nitidum and found that it exhibited antiinflammatory, antiandrogenic cancer preventive, dermatitigenic hypocholesterolemic, 5alpha reductase inhibitor, anemiagenic insectifuge, and flavor.

\subsection{Shyobunone $\left(\mathrm{C}_{15} \mathrm{H}_{24} \mathrm{O}\right)$}

GC-MS analysis suggested the presence of shyobunone in Acorus calamus (Fig. 5). Shyobunone, found in Acorus calamus, has been reported to exhibit biological activity. Ganjewala et al. [3] reported presence of Shyobunone (besides other compounds) in the rhizome extract of A. calamus, which are reported for anti-oxidant, anti-microbial, antiinflammatory, nematicide and hypocholesterolemic activities.

Chen et al. [25] found that shyobunone $(9.60 \%)$ was one of the main components of essential oil derived from $A$. calamus rhizomes and it displayed insecticidal and repellant activity against Lasioderma serricorne (LS) and Tribolium castaneum (TC). On the contrary, Akram et al. [26] reported that Shyobunone, a keto compound found in the ethanolic extract of rhizome of A. calamus, did not exhibit any biological activity.

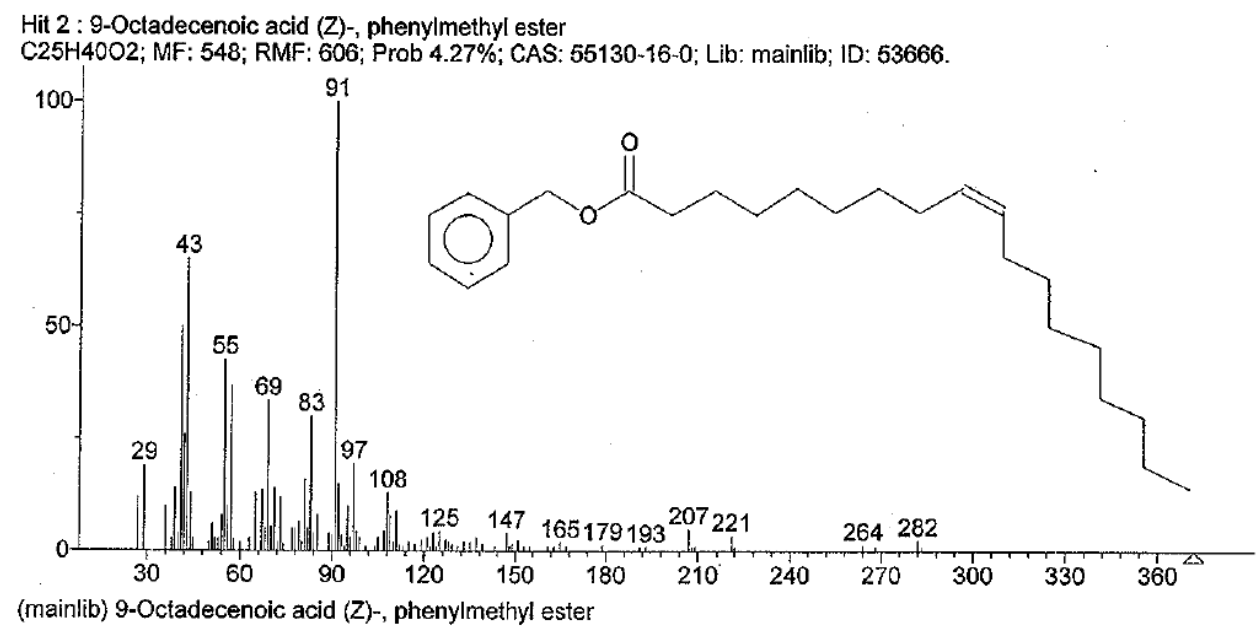

Fig. 4. Chromatogram of compound 9-0ctadecenoic acid (Z)-, phenylmethyl ester. 


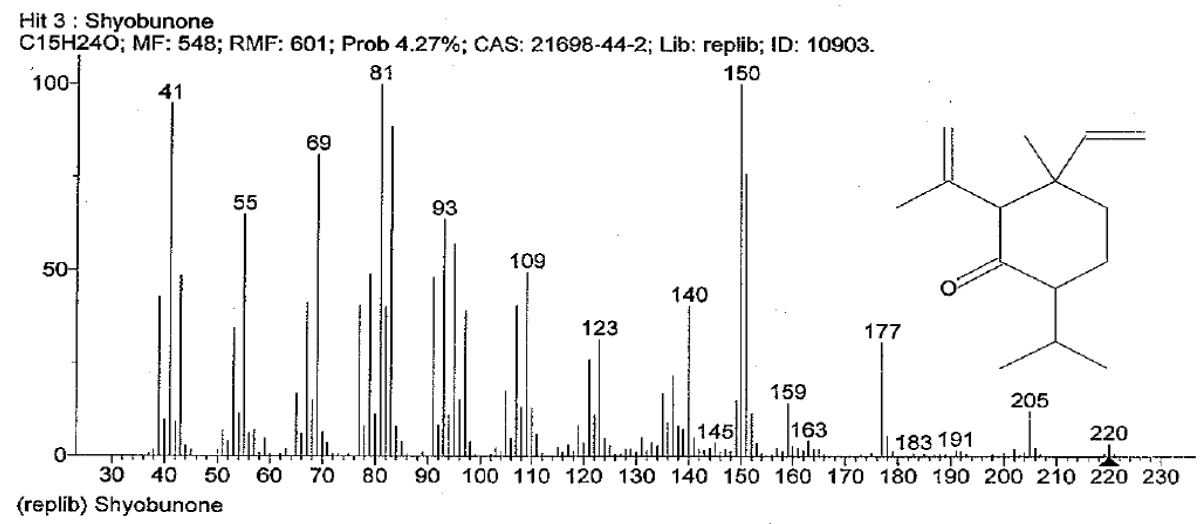

Fig. 5. Chromatogram of compound Shyobunone.

\subsection{Asarone}

GC-MS analysis suggested the presence of asarone in Acorus calamus (Fig. 6). Asarone found in Acorus calamus has been reported to exhibit anti-microbal activity. Liu et al. [27] determined the chemical composition of the essential oil of Acorus calamus rhizomes in China and identified 32 components of the essential oil of A. calamus rhizomes, in which $\alpha$-asarone (comprising $50.1 \%$ of total compounds present) was the principal compound. They reported the insecticidal activity of A. calamus against the booklouse (Liposcelis bostrychophila). Kumar et al. [28], Manikandan and Devi [29]; Devi and Ganjewala [30]; Devi et al. [31] have reported presence of $\alpha$-asarone in the rhizome extract of A. calamus. Ganjewala et al. [3] evaluated anti-microbial activity of Acorus calamus rhizome and leaf extracts obtained with different solvents viz., petroleum ether, chloroform, hexane and ethyl acetate and reported that $\alpha$ and $\beta$-asarones were primarily responsible for anti-microbial activities of A. calamus. The anti-fungal activity of petroleum ether and ethanolic extracts of the rhizome of Acorus calamus could, inter alia, probably be due to the presence of compounds (viz. Shyobunone and $\alpha$-Asarone). Kumar et al. [28] had also reported presence of Shyobunone, and $\alpha$-Asarone, (besides other compounds) in the rhizome extract of A. calamus, which are reported for anti-oxidant, anti-microbial, anti-inflammatory, nematicide and hypo-cholesterolemic activities. Manikandan and Devi [29]; Devi and Ganjewala [30]; Devi et al. [31] have attributed $\alpha$ Asarone, which is one of major phyto-chemical compounds found in methanolic extract of A. calamus, for anti-oxidant activity. Lee [32] reported fungicidal activity of alphaasarone and asaron aldehyde derived from Acorus gramineus rhizomes against Rhizoctonia solani and Phytopthora infestans. 


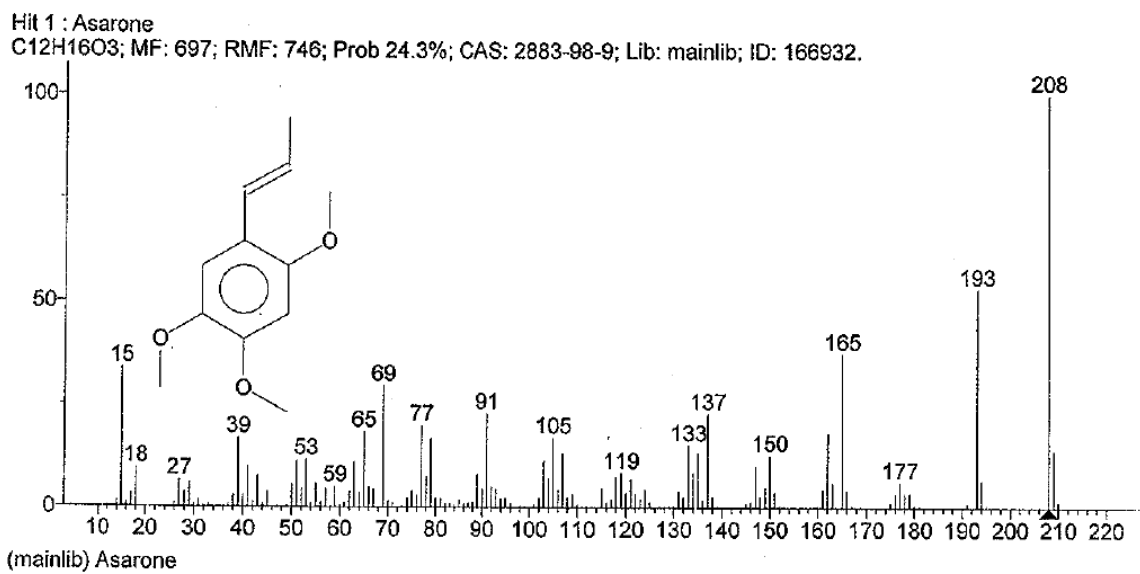

Fig. 6. Chromatogram of compound Asarone.

\subsection{Benzene, 1,2,3-trimethoxy-5-(2-propenyl)-( $\left(\mathrm{C}_{12} \mathrm{H}_{16} \mathrm{O}_{3}\right)$}

GC-MS analysis suggested the presence of this compound in Acorus calamus (Fig. 7). Nikhila et al. [33] found benzene, 1,2,3-trimethoxy-5-(2-propenyl)- $\left(\mathrm{C}_{12} \mathrm{H}_{16} \mathrm{O}_{3}\right)$ as one of the medicinally active compounds from tuber of Gloriosa superba by GC-MS, which possessed anti-microbial activity. Yang et al. [34] reported that 'Benzene, 1,2,3trimethoxy-5-(2-propenyl) (Elemicin)' is one of the organic compounds in Dalbergia bariensis wood and it has hypnotic and ant-septic effects. Atalar and Turkan [35] reported the presence of this compound in rhizome of Acorus calamus, besides asarone.

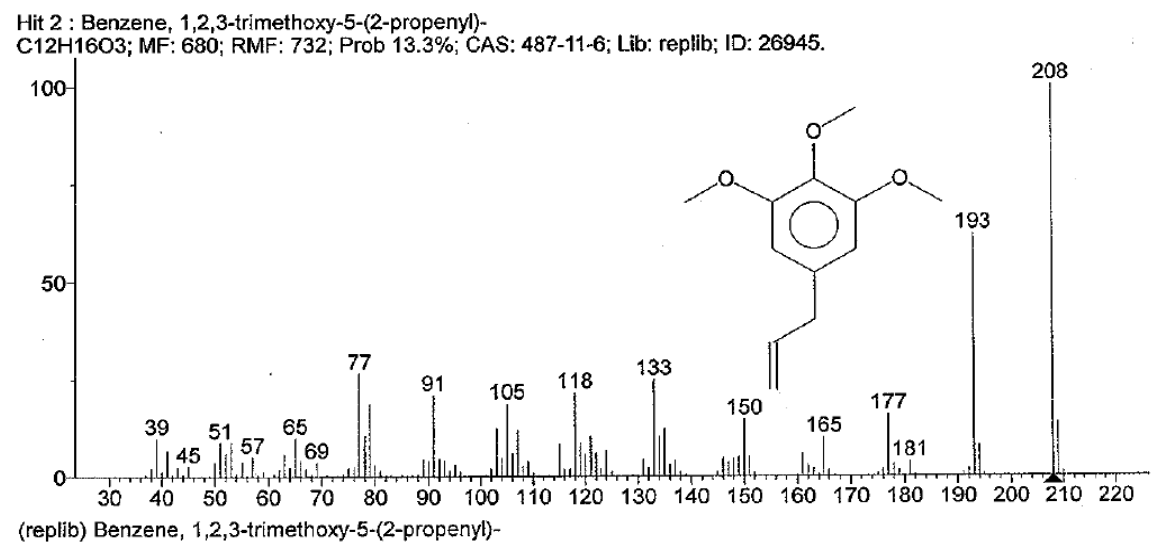

Fig. 7. Chromatogram of compound Benzene, 1,2,3-trimethoxy-5-(2-propenyl)- $\left(\mathrm{C}_{12} \mathrm{H}_{16} \mathrm{O}_{3}\right)$.

\section{Conclusion}

Acorus calamus finds wider application as a herbal medicine owing to its anti-microbial activity [36]. The therapeutic potential of A. calamus derives from the presence of some 
compounds, which have been reported to retard the growth of various pathogens, as reported in the preceding sections. Given the incidence of such compounds (with therapeutic properties) in Acorus calamus rhizome, this study seeks to identify them using GC-MS analysis.

GC-MS analysis (for investigation of the compounds present) of the petroleum ether extract of A. calamus rhizome suggested the presence of five compounds (which showed close match with those of the GC-MS database main library of Novocatalyz) viz., Spiro[2,4,5,6,7,7a-hexahydro-2-oxo-4,4,7a-trimethylbenzofuran]-7,2'-(oxirane); 9-Octadecenoic acid (Z)-, phenylmethyl ester $\left(\mathrm{C}_{25} \mathrm{H}_{40} \mathrm{O}_{2}\right)$; Shyobunone; $\alpha$-Asarone; and benzene, 1,2,3-trime-thoxy-5-(2-propenyl)- $\left(\mathrm{C}_{12} \mathrm{H}_{16} \mathrm{O}_{3}\right)$. Presence of some of these phyto-chemicals may be responsible for the anti-microbial activity of Acorus calamus. Findings of various studies [3,27-31] in respect of rhizome of Acorus calamus suggest that presence of shynobunone and asarone may have been responsible for its anti-oxidant and antimicrobial activities.

However, in-depth research is needed on the bio-active constituent compounds of essential oils of Acorus calamus. This is because of the fact that there may be significant differences in biosynthesis, composition, structure, etc. of bio-active constituent compounds across various varieties, species (and even within the same species) owing to different environmental and various other abiotic constraints such as water stress, level of pollution, etc. Liu et al. [27] attributed that differences of chemical composition of the essential oils of $A$. calamus could be due to harvest time and local, climatic and seasonal factors as well as storage duration of medicinal herbs. Also, different species may have distinct characteristics. Future works on this area may, inter alia, attempt to correlate these isolated compounds with their anti-microbial activity and anti-oxidant capacity.

\section{Acknowledgments}

Authors are thankful to the support staff of the respective Department of Botany and B. Herbarium of St. Xavier's College, Mumbai and Ranchi University, Ranchi for their support in collection and identification of plants. First author is grateful to U. C. Bapat, Former HOD, Department of Botany, St. Xavier's College, Mumbai for her guidance. Authors are thankful to Novacatalyz Laboratory (Bangalore) for GC-MS analysis for authentic identification of constituent compounds present in the plant extracts.

\section{References}

1. M. H. Abass and N. H. Mohammed, Basra J. Date Palm Res. 13, 26 (2014).

2. S. S. Kumar, A. A. Soban, A. T. S. Fareed, and J. M. S Mohamed, Orient. J. Chem. 26, 223 (2010).

3. D. Ganjewala and S. A. Devi, Acta Biol. Szeged. 53, 45 (2009).

4. R. Balakumbahan, K. Rajamani, and K. Kumanan, J. Med. Plant Res. 4, 2740 (2010).

5. S. T. Runkel, A. F. Bull, L. A. Stone, T. Rosburg, C. Kurtz, L. Scarth, R. Scarth, Wildflowers of Iowa Woodlands (University of Lowa Press, 2009). https://doi.org/10.2307/j.ctt20mvcrz

6. U. C. Bapat, S. Prabha, and J. Kumar, Int. J. Bioassays 5, 4714 (2016). https://doi.org/10.21746/ijbio.2016.07.0012 
7. S. Prabha, U. C. Bapat, and J. Kumar. Eur. J. Pharm. Med. Res. 3, 583 (2016).

8. W. Dong, D. Yang, and R. Lu, Planta Med. 76, 454 (2010). https://doi.org/10.1055/s-0029-1186217

9. R. Gyawali and K. S. Kim, Kathmandu Univ. J. Sci. Eng. Technol. 5, 51 (2009).

10. A. Muthuraman and S. Nirmal, Asian Pac. J. Trop. Biomed. 2, S1017 (2012). https://doi.org/10.1016/S2221-1691(12)60354-2

11. N. Mittal, H. S. Ginwal, and V. K. Varshney, Pharmacog. Rev. 3, 83 (2009).

12. D. Wang, Y. Geng, L. Fang, X. Shu, J. Liu, X. Wang, and H. Luqi, J. Sep. Sci. 34, 3339 (2011). https://doi.org/10.1002/jssc.201100573

13. D. Sandeep and C. K. Nair, Mutat. Res. 722, 62 (2011). https://doi.org/10.1016/j.mrgentox.2011.03.005

14. D. Ganjewala and A. Devi, Acta Biol. Szeged. 53, 45 (2009).

15. S. Phongpaichit, N. Pujenjob, V. Rukachaisirikul, and M. M. Ongsakul, J. Sci. Technol. 27, 517 (2005).

16. M. Ghosh, Ann. Bot. 98, 1145 (2006). https://doi.org/10.1093/aob/mcl205

17. C. Singh, U. Jamwal, and P. Singh, JMAPS 23, 687 (2001).

18. P. D. Shah, M. Ghag, P. B. Deshmukh, Y. Kulkarni, S. V. Joshi, B. A. Vyas, and S. R. Dinesh, Int. J. Green Pharm. 6, 29 (2012). https://doi.org/10.4103/0973-8258.97119

19. H. H. Haines, The Botany of Bihar \& Orissa, 1-3: 1-1372 (1924). [Reprint (1961)].

20. E. M. Kuskoski, J. R. José, M. B. Julia, F. Roseane, M. T. Ana, and, G. A. Agustín, Open Analyt. Chem. J. 6, 1 (2012).

21. G. M. Channabasava, C. P. Chandrappa, and T. S. Sadananda, Asian J. Pharm. 4, 34 (2014).

22. T. K. S. Kumari, S. Muthukumarasamy, and V. Mohan, Sci. Res. Reporter 2, 187 (2012).

23. V. Bharathy and F. Uthayakumari, Int. J. Pharm. Tech. Res. Coden (USA), 5, 1839 (2013).

24. M. N. Das, S. Sivakama, K. S. Sundari. V. Mohan, and B. Parthipan, Asian J. Pharm. Clin. Res. 7, 2 (2014).

25. H. P. Chen, K. Yang, L. S. Zheng, C. X. You, Q. Cai, and C. F. Wang, Pharmacogn Mag. 11, 675 (2015). https://doi.org/10.4103/0973-1296.165543

26. S. Akram, S. S. Kumar, A. Fareed, T. S. Ahmed, and J. M. S. Mohamed, Orient. J. Chem. 26, 223 (2010).

27. X. C. Liu, L. G. Zhou; Z. L. Liu, and S. S. Du. Molecules 18, 5684 (2013). https://doi.org/10.3390/molecules 18055684

28. S. S. Kumar, A. S. Akram; T. S. F. Ahmed, and M. S. M. Jaabir, Orient. J. Chem. 26, 223 (2010).

29. S. Manikandan and R. S. Devi, Pharmacol. Res. 52, 467 (2005). https://doi.org/10.1016/j.phrs.2005.07.007

30. S. A. Devi and D. J. Ganjewala, Herbs Spiced Med. Plants 17, 1 (2011). https://doi.org/10.1080/10496475.2010.509659

31. A. S. Devi, A. L. Mali, M. A. Rahee, and E. D. S. Belinda, Asian J. Chem. 9, 107 (2014). https://doi.org/10.3923/ajb.2014.107.113

32. H. S. Lee, Bioresour. Technol. 98, 1324 (2007). https://doi.org/10.1016/j.biortech.2006.05.018

33. G. S, Nikhila, G. Sangeetha, T. S. Preetha, and T. S. Swapna, J. Pharmacogn. Phytochem. 5, 17 (2016).

34. L. Yang, T. Jiang, H. Liu, and K. Li, BioResources 10, 7092 (2015). https://doi.org/10.15376/biores.10.4.7092-7104

35. A. M. Nuri and F. Türkan, J. Inst. Sci. Technol. 8, 181 (2018). https://doi.org/10.21597/jist.433743

36. S. Prabha, S. H. Gaurea, U. C. Bapat, and K. Jyoti, Eur. J. Pharm. Med. Res. 6, 357 (2019). 